\title{
An Overburdened Term: Dewey's Concept of "Experience" as Curriculum Theory
}

\section{Jayson Seaman and Peter J. Nelsen}

From the start, John Dewey's ideas about education have been prone to misunderstanding. One of the greatest casualties has been "experience," a term so routinely misappropriated that Dewey ultimately decided to abandon it. He wrote, "I would abandon the term 'experience' because of my growing realization that the historical obstacles which prevented understanding of my use of'experience' are, for all practical purposes, insurmountable. I would substitute the term 'culture' because with its meanings as now firmly established it can fully and freely carry my philosophy of experience" (1981, p. 361). Dewey evidently recognized that a main challenge to understanding experience was the conceptual weight the term had been made to carry. Because it was so central to his entire metaphysics, the challenge of understanding experience spills over into the project of grasping his vision for schooling, including what he was fundamentally attempting to do by employing experience in an educational sense in the first place. Adding to this challenge is the range and organization of Dewey's ideas on the matter: he sometimes wrote or lectured about experience and education together (1938), sometimes independently (1932, 1934a, $1990)$, and sometimes in relation to other issues $(1899,1958,1980)$. He also did not always mention them directly, yet they are often implicated in discussions of other topics (1999a, 1999b). After devoting so much time to developing his concept of experience over the years, it is noteworthy that Dewey abandoned it; he might have anticipated the misconstruals that would persist throughout the latter half of the twentieth century as they did in the first.

In this article, Dewey's core educational concept of experience is interpreted in light of his broader aims for reconstructing American democracy, his critique of political economy, and his identification with anthropological thought. We mean to propose a more expansive interpretation of experience than what is commonly represented in the educational literature. We suggest that, for Dewey, experience was a polysemic term serving several functions across different philosophical con- 
cerns: it tethered thinking to practical activity, invoked the interactional nature of human existence, and functioned as an integrating principle that helped reconcile contradictions among theoretical domains, from psychology to cultural-historical evolution. The concept also led Dewey to formulate a curricular logic based primarily on anthropological themes, which, although most concretely developed while he was at the University of Chicago, informed his ongoing critique of other theories that conceived of curriculum in terms of transmitting disciplinary knowledge and maximizing educational outcomes for individuals, which Dewey argued only perpetuated social problems (Westbrook, 1993). Our aim is to suggest that experience, when applied educationally, should be interpreted in light of Dewey's larger effort to establish democratic controls over an increasingly corrosive social, economic, and psychological order brought about by industrial capitalism.

Our argument is motivated by the way experience is often attributed to Dewey in the contemporary educational literature, especially in the experiential or experience-based learning (EBL) tradition, where he is frequently named as the foremost intellectual progenitor in foundational (e.g., Boud, Keogh, \& Walker, 1985; Kolb, 1984; Moon, 2004) and applied texts (e.g., Beard \& Wilson, 2006; Wurdinger, 2005). Despite his presumed influence in this literature, the connections between Dewey's notion of experience and his broader political, educational, and philosophical agendas are often underspecified, stripping the concept of important meaning. EBL advocates are not the sole claimants to a Deweyan heritage, however; many social justice and civic educators cite his emphasis on critical reflection and democratic life, yet they do not often make experience a central focus or emphasize his pragmatism within their discussions. For example, in the recently published Handbook of Critical Education (Apple, Au, \& Gandin, 2009), Dewey's arguments regarding the relationship of education and democracy are referenced several times without indicating what they imply about a comprehensive curriculum for critical education.

We believe Dewey's educational use of experience could inform such a curriculum, but, because of existing interpretations and omissions, the concept tends to suffer from three reductions at the hands of advocates and critics alike: as an apolitical pedagogy of learning by doing, as one that emphasizes collectivist democratic participation but is insufficiently political, or as one that is sufficiently political but unsystematic in its approach to education. ${ }^{1}$ Such judgments, we argue, emerge from an under-examination of Dewey's principle of experience. We propose that the concept helped Dewey establish a coherent curriculum theory that was far-reaching in its implications for schooling, but it is understandable only in light of his more encompassing aim to rescue the promise of democracy from the deleterious effects of industrial capitalism so the spoils of technological progress could be directed to more humane and individually fulfilling ends.

Our argument proceeds as follows. In the first section we review Dewey's characterization in the EBL literature, which tends to conflate experience with student-centered constructivism. In the second section, we build a background for 
understanding Dewey's curricular logic by drawing upon several of his social and political essays that critique industrial capitalism as an economic and ideological system. We also discuss Dewey's conceptualization of individualism as a historical construct and consciousness as socially constituted, since this shapes the educational meaning of experience in substantial ways. In the third section we review Dewey's unique curricular logic, particularly his adoption of culture-epochs as an organizing scheme and occupations as a main instructional vehicle (DeFalco, 2010; Fallace, 2008). These are concretely realized experiences in any given instance and they also evidence his enduring view that the concept should systematically inform curriculum design, specifically in service of the historical changes he envisioned. We conclude by briefly reviewing current curricular models that reflect the priorities outlined in the body of the article. We point to the growing critical pragmatist literature as well as that of contemporary activity theorists, since we see these as highly relevant to future inquiry into experience as a Deweyan tradition.

\section{Experience, not Experiential}

Nowhere are references to experience more ubiquitous, yet its meaning more opaque, than in the EBL literature. Here, Dewey's contribution is typically presented as follows: "Dewey championed education for democracy and placed emphasis on active learning, experimentation, and problem solving. Dewey's pragmatic approach connects theory with practice and requires students to similarly connect reflection with action" (Kellner \& Share, 2007, p. 65). On the one hand, these clearly are pedagogical elements that Dewey promoted. On the other hand, authors rarely make any explicit connection between key terms like experimentation, problem solving, and reflection and the core curricular issues of scope and sequence and subject matter, all of which remained career-long preoccupations for Dewey. For instance, in Experience and Education, he writes: "Unless experience is so conceived that the result is a plan for deciding upon subject matter, upon methods of instruction and discipline, and upon material equipment and social organization of the school, it is wholly in the air" (1938, p. 28). Despite this demand for specificity in such a canonical text, the EBL literature often makes experience out to have no coherent essence, inviting readers to project their own ideas onto it and giving the impression that Dewey's educational philosophy is less programmatic and more flexible than it actually was. Carver and Enfield (2006) express this view: “Dewey's philosophy provides a lens for seeing the quality of educational experiences. It does not provide a template for building an educational program" (p. 56). This position risks reducing experience simply to a set of criteria for designing learning activities that are more participatory than other alternatives.

This interpretation has underwritten a range of practices, from those that approximate real-world situations to those intended to enrich classroom lessons. In one overview of the EBL field, Andresen, Boud, and Cohen (1999) list the following: "internships, work placement, on-the-job training, excursions, adventure and 
wilderness trips, studios, laboratories, workshops, clinicals, practicums, case study approaches, action research, role plays, hypotheticals, and simulations," along with "active learning in lectures, computer simulations, use of realistic models, videobased activities, group discussions and syndicate methods, autobiographical writing, problem-based learning, group work, use of reflective journals and self-directed projects" (p. 231). The catalog provided by the authors presumably illustrates the extent to which experience has permeated practice, but, borrowing a phrase from Jane Margolis, it also makes it seem like a coat closet-"you can hang anything on it" (as cited in Maxwell, 2005, p. 43). Dewey's own misgivings about the term should raise doubt that the concept can plausibly be stretched across all of the uses found in the literature and in practice without becoming essentially meaningless. We take this to be Kliebard's (1995) point when he argues that Dewey's ideas are often reduced to "a pitiful caricature, such as learning by doing" (p. 27).

Our aim here is not to prove that EBL advocates have got Dewey wrong in any absolute sense. Indeed, some of their major priorities reflect Deweyan themes: educators ought to promote reflective thinking, foster social dispositions, create cooperative environments, make knowledge relevant to the learner, develop problemsolving skills, encourage lifelong learning, build connections to the community, help create socially just institutions, and so on. But most conceptions of experience-based learning stop here, which still falls short of grasping Dewey's full conception. Our purpose is therefore to outline a more expansive interpretation of experience to serve as a reference point for future forms of so-called experience-based education.

It will be useful to keep Dewey's turn toward culture in mind throughout our discussion, since this indicates the order of conceptual magnitude he had in mind in applying experience to education. For him, any practice, and any theory that supports it, can be considered educative only when "extended to include how this and that social condition works causally to modify the experience and affect the character and capacity of individuals who come under its influence" (Dewey, 1933, p. 82), an accomplishment requiring "a well-thought out philosophy of the social factors that operate in the constitution of individual experience" (1938, p. 21). These social factors were historically, politically, economically, and geographically expansive, and he argued vociferously for their consideration in theories of curriculum.

\section{Economic Dimensions of Experience and their Influence on Schooling}

Foremost in Dewey's thinking was the significance of industrial production and distribution in determining the course of modern historical events, including those shaping the nature of education. He discusses this as early as 1899, in The School and Social Progress:

The [social] change that ... overshadows and controls all the others, is the industrial one-the application of science resulting in the great inventions that have utilized the forces of nature on a vast and inexpensive scale: the 
growth of a world-wide market as the object of production, of vast manufacturing centers to supply this market, of cheap and rapid means of communication and distribution between all its parts ... Through it, the face of the earth is making over, even as to its physical forms; political boundaries are wiped out and moved about, as if they were indeed only lines on a paper map; population is hurriedly gathered into cities from the ends of the earth; habits of living are altered with startling abruptness and thoroughness; the search for the truths of nature is infinitely stimulated and facilitated, and their application to life not only practicable, but commercially necessary. Even our moral and religious ideas and interests, the most conservative because the deepest-lying things in our nature, are profoundly affected. That this revolution should not affect education in some other than a formal and superficial fashion is inconceivable. (pp. 456-457)

The passage above signals Dewey's awareness of the impact of industry on human association, an analysis he would continue to develop to the point where, in 1930, he concluded bluntly: "economic determinism is now a fact, not a theory" (p. 58). Here he approaches Marx in his critique of political economy, and because industrial capitalism ushered in such a major world-historical change, it figured prominently in his thinking about social problems and their possible educational remedies. The passage below elaborates on this early awareness, forming the basis of the educational priorities he expounded over the next 40 years:

At present, impulses which lie at the basis of the industrial system are either practically neglected or positively distorted during the school period. Until the instincts of construction and production are systematically laid hold of in the years of childhood and youth, until they are trained in social directions, enriched by historical interpretation, controlled and illuminated by scientific methods, we certainly are in no position even to locate the source of our economic evils, much less to deal with them effectively. (pp. 464-465)

In these passages, Dewey throws down the gauntlet for modern curriculum theorists. His own vision was to develop a system of education that would "lay hold of" human creative impulses, realized through processes of individual development and societal production - that is, play and labor-and prevent them from being distorted by the economic forces of capitalism, aiming them instead to rationally deliberated, humanely social, and individually fulfilling ends. In his terms, "the ultimate place of economic organization in human life is to assure the secure basis for an ordered expression of individual capacity and for the satisfaction of the needs of man in noneconomic directions" (Dewey, 1999b, p. 88). This formed the heart of Dewey's progressive agenda and also represented the educational challenge to which experience would be put.

Realizing Dewey's progressive aims not only involved the practical matter of designing a new curriculum, however. It also created a need to solve deeper philosophical problems. Liberalism had so far provided the foundation for aims such as 
the "ordered expression of individual capacity," but in Dewey's view, the historical accomplishments of liberalism had been distorted by capitalism. He saw the need to rearrange the priorities of the individual and social over the economic, for until this occurred, America's structural problems would persist and both individual potential and cultural evolution would be thwarted. But, in contrast to other liberal reformers of his day, whom he derided, Dewey's democratic vision was fully pragmatic; it "does not tell us to 're-arm morally' and all social problems would be solved. It says, Find out how the constituents of our existing culture are operating and then see to it that whenever and wherever needed they be modified in order that their workings may release and fulfill the possibilities of human nature" (1989, p. 98). These constituents involved both societal relations and individual consciousness.

\section{Societal relations}

Dewey's writing about the antidemocratic forces of industrial capitalism is especially direct during and after the Depression. He reported "vast and concentrated aggregations of wealth; there are monopolies of power; great unemployment; a shutting down of doors of opportunity, a gulf between rich and poor, and no frontier to which the hard-put can migrate. In consequence, the problem of democracy is no longer chiefly governmental and political. It is industrial and financial-economic" (1932, p. 96). The depression had made it clear that America's democratic promise would be realized only with conscious attention to economic forces. While they were most overtly visible in class relations, they had also permeated the social institutions responsible for cultural evolution, namely, science and education. In Experience and Education (1938), Dewey wrote: "[the economic and industrial problems of the present society] ... are the products to a very large extent of the application of science in production and distribution of commodities and services, while the latter processes are the most important factor in determining the present relations of human beings and social groups to one another" (p. 80).

Here, as elsewhere, Dewey regards science as the highest source of modern knowledge and technological innovation, and capitalism as the force that had accelerated its progress and distributed its spoils unequally. One of his main educational aims was thus to elevate scientific reasoning over economic logic, effectively reversing modern trends. This not only meant practicing the experimental method in schools as a formal procedure, it involved the way knowledge distribution was conceived within competing curricular ideologies. Dewey's argument was therefore economic and political as well as epistemological: powerful class divisions that were "a heritage from the institutions of a prescientific age" (1938, p. 81) controlled not just the distribution of goods and services, but the way knowledge was organized within school curricula. He wrote: "The last stand of oligarchical and anti-social seclusion is perpetuation of this purely individualistic notion of intelligence" (1999b, p. 57). Dewey linked the individualistic view of mind to the social conditions of capitalism, which sponsors “the division into 'cultured' people and 'workers,' the separation of 
theory and practice" (1899, p. 466). Other curricular ideologies viewing culture and intelligence as individual properties were therefore complicit in social problems, and schooling based on these ideas would only perpetuate economic disparities. As a result, doing away with theory/practice dualisms was both an intellectual task and also a social and economic one, requiring a radically different program than those entailed by other curriculum theories.

The interactional dimension of experience provided one foundation for such a program. Dewey eschewed the privatization of knowledge and instead wanted it to be "put into circulation" (Dewey, 1899, p. 465), fomenting an "intellectual revolution" that was necessarily also a political revolution. But, in contrast to a Marxist uprising-a reading of history he saw unfolding tragically in Stalinist Russia (see Dewey, 1934b; 1989, ch. 4) -Dewey saw active, democratic education as a key method for consciously redistributing cultural resources and life opportunities so that economic activities would be made "servants of the development of the higher capacities of individuals" (Dewey, 1991, p. 40) rather than the other way around. Collaboration was of course central to this project, enabling children to actively appropriate cultural funds of knowledge and contribute creatively to them. However, the idea that education could be leveraged to consciously redirect social forces also implicated existing theories of individualism.

\section{Historicizing the individual}

Dewey's social critique did not stop with broad historical trends; it included the formation of individual consciousness as well as the way mind itself was conceived. Throughout several social and political texts Dewey stated unequivocally that individualism itself is socially and historically constituted. In Freedom and Culture (1989), he wrote: "Whether complete identification of human nature with individuality would be desirable or undesirable if it existed is an idle academic question. For it does not exist" (p. 24). In Individualism, Old and New (1999) he stated as "fact" that "the mental and moral structure of individuals, the pattern of their desires and purposes, change with every great change in social constitution ... producing the framework of personal disposition" (pp. 40-41). Even morality, which seems to have prima facie status as an attribute of individual reflection, should not be conceived as the "conscious testing of conduct by an inner and self-imposed standard" but operates "largely through habit rather than through choice" (Dewey \& Tufts, 1909, p. 31). In short, learning and development are thoroughly social processes and could not be understood through existing, atomistic theories of individualism.

One way to understand Dewey's critique of competing curriculum theories is through this line of argumentation. The domination of capitalism over social, political, and economic life, what he called "corporateness," had become "internal ... realized in thought and purpose ... qualitative" (Dewey, 1999b, p. 25); it had altered human subjectivity. Moreover, with the invention of the machine, he argued, industry and business had developed "a scope and power they never had in the past 
from which they derive," perverting "the whole ideal of individualism to conform to the practices of a pecuniary culture" and becoming "the source and justification of inequalities and oppressions" (Dewey, 1999b, p. 9). Here Dewey foregrounds the individual less so learners might be conceived as social beings with compelling personal biographies, and more to draw attention to the way individualism itself had functioned as a belief system over time. The hegemony of industrial capitalism-accelerated by technological developments and shored up by liberal theories that, although successful in supporting individual sovereignty in the waning days of feudalism, were now obsolete-had transformed the promise of the individual from a sovereign political entity into a structurally bound economic one.

This conclusion shaped the specific version of liberal theory Dewey adopted, which he called "radical liberalism" and "fighting liberalism." In Liberalism and Social Action (1991) he argued that "liberalism that takes its profession of the importance of individuality with sincerity must be deeply concerned about the structure of human association" (p. 48). Through his brand of liberalism Dewey stressed the need for strong controls to overcome capitalism's fracturing effects:

The only form of enduring social organization that is now possible is one in which the new forces of production are cooperatively controlled and used in the interest of the effective liberty and the cultural development of the individuals that constitute society.... Organized social planning, put into effect for the creation of an order in which industry and finance are socially directed in behalf of institutions that provide the material basis for the cultural liberation and growth of individuals, is now the sole method of social action by which liberalism can realize its professed aims. (1991, pp. 59-60)

Dewey targets other philosophers here, but the political commitments he expresses undergird his vision for education, specifically, that it should enable "organized social planning" by acting as a two-pronged lever for "cultural liberation" from economic forces as well as "growth of individuals." This monistic argument was aimed at his contemporaries who, he wrote, "define liberalism in terms of the old opposition between the province of organized social action and the province of purely individual initiative and effort," arguing that "wittingly or unwittingly, they still provide the intellectual system of apologetics for the existing economic regime, which they strangely, it would seem ironically, uphold as a regime of individual liberty for all" (1991, p. 35). Individualism, the centerpiece of classical liberal theory, now served as a system of justification for class divisions, social problems, and moral depravations, a point that impugned competing curricular ideologies founded on it. In contrast, experience conveyed the significance of individual agency not merely as an expression of will, but as a historical intervention into modern consciousness.

To summarize, Dewey's broad aims involved developing a conceptual system capable of helping control the economic forces of production, distribution, and consumption through regulative means at various levels: the state, the local community, and individual subjectivity. An obvious and primary mechanism for effecting 
these changes was the school, where the desire to form a "new psychological and moral type" (Dewey, 1999b, p. 40) of individual would be "achieved only through the controlled use of all the resources of science and technology that have mastered the physical forces of nature" (p. 46). An adequate curriculum theory would outline how this could be accomplished without perpetuating economic injustices or resorting to indoctrination. In Dewey's view, other proposals failed on these accounts.

Dewey's unique solution was to have children learn to direct scientific and technological processes and remake themselves as democratic agents in curriculum organized around experience. A more collaborative and socially organized form of schooling would be the primary way "cooperative experimental intelligence finds its way into the working structure of individuals" (Dewey, 1999b, p. 53). To this end, experience served as both a principle for practice and as an integrative concept that would systematically help solve some of the problems he detected in other theories, namely, their complicity in perpetuating capitalist ideologies at the expense of democratic, social, and individual development. And because their practices reflected faulty theorizing, also needed was a curricular logic that would yield new ways of teaching and learning capable of serving the social and political ends Dewey sought. In order to illustrate what this specifically meant for Dewey, we turn to ideas he elaborated most during the Lab School period.

\section{Dewey's Curricular Logic: Culture Epochs and Occupations}

Dewey's affinity for a culture concept is apparent early on. His Pedagogic Creed (1897) begins by linking the individual and culture through education: "I believe that all education proceeds by the participation of the individual in the social consciousness of the race... Through this unconscious education the individual gradually comes to share in the intellectual and moral resources which humanity has succeeded in getting together. He becomes an inheritor of the funded capital of civilization" (para. 1). Here Dewey is stating a basic assumption: the task of schooling is to direct these naturally occurring processes in socially productive and individually fulfilling directions. How best to accomplish this was (and is) the problem facing curriculum theorists, and Dewey's logic on this point was perhaps clearest as he was establishing his school at the University of Chicago (Kliebard, 2006). Two guiding concepts, detailed most during this period, served as a means of organization and a mode of delivery: culture epochs and occupations.

\section{Culture epochs}

Fallace (2008) discusses two major influences on the social sciences at the turn of the nineteenth century: evolutionary psychology and anthropology. These influences, he notes, indelibly shaped Dewey's thinking. Despite later being discredited, one idea popular among Herbartian reformers, with whom Dewey was briefly affiliated, left a particular mark on his thinking: ontogeny recapitulates phylogeny. In curricular terms, this meant that "the cultural products of each epoch will contain 
that which appeals most sympathetically and closely to the child at that epoch" (Dewey, 1896a, p. 247). Put otherwise, this view held that children's developmental stages "corresponded with the evolutionary stages of Western civilization" (Fallace, p. 383). Thus, when Dewey argued that learning involves "repeating the race experience" (Dewey, 1896b, p. 440), he implies that children's psychological growth can be reconciled with knowledge of cultural evolution (Fallace). Educationally, this means that children progressively come to understand disciplinary knowledge in "a fuller and richer and also more organized form, a form that gradually approximates that in which subject matter is presented to the skilled, mature person" (Dewey, 1938, p. 74).

Despite his affinity for the general idea, Dewey scorned the belief that individual development corresponded literally to phases in human evolution (see 1896a). But, in providing an "orderly and cumulative narrative" (Dewey, 1900, p. 223), the ontogeny recapitulates phylogeny idea furnished Dewey with a practically useful and conceptually rich way to consider curriculum organization. Importantly, this separated him from humanists, who advocated for the organization of knowledge through the disciplines of history, science, literature, Latin, and so on (Kliebard, 1995). Dewey rejected these divisions but agreed with humanists in one respect: that schooling's main aim is to promote the mastery of civilizational funds of knowledge. He wrote in 1899: "All that society has accomplished for itself is put, through the agency of the school, at the disposal of its future members" (p. 455). Dewey also criticized humanists on the grounds that presenting disciplinary knowledge as a finished product required that interest be generated from outside the student (using "devices of art to cover up the imposition"; 1938, p. 19). He instead saw interest and subject matter as two sides of the same coin, a fluid aspect of ongoing social practices.

Turning to social practices and not individual psychology as the unit of concern solved both a conceptual and a pedagogical problem: involving children directly in these practices would naturally unite interest and subject matter, eliminating their dichotomy (this was a main subject in The Child and the Curriculum). It also addressed a political issue, since, through the culture epochs approach, "the mind is introduced to much more fundamental and controlling influences than appear in the political and chronological records that usually pass for history" (Dewey, 1899, p. 463). The "fundamental and controlling influences" to which he refers are human needs and impulses on the one hand, and the availability of natural and cultural resources to fulfill them, on the other.

Dewey was critical of other culture epochs adherents, particularly those who used literature to convey knowledge of an era that presumably aligned with a child's psychological stage. He took a thematic, rather than a literal, view of the theory:

Children are interested directly in present life, in the social conditions which exist all about them and with which they come in contact; and any genuine, any educative historic interest is simply a reflex of this interest in the existing social structure. If there be such a thing in the child 
as a nomadic interest, it finds its natural and direct prey not in the shifting hordes of semi-barbaric tribes as they wandered with the flocks over half-barren territory, but in the railway and steamboat before his eyes . . . Let this movement be realized and then there is a basis for considering other modes of movements, and other relationships between ox and man! (Dewey, 1896a, pp. 251-252)

Seeing culture epochs thematically prompted Dewey to promote active participation in social practices rather than simply to read about them. This led him to develop specific meanings and functions for concepts like "interest" and "relevance." For him, they began with a consideration of subject matter, child psychology, and anthropology, and not merely with the interests of individual children in a given lesson. In fact, he repudiated this practice: "The child has his own instincts and tendencies, but we do not know what these mean until we can translate them into their social equivalents. We must be able to carry them back into a social past and see them as the inheritance of previous race activities" (Dewey, 1897, para 4). Interest and relevance as key features of experience were not stand-alone concepts, but captured the unity of emerging psychological stages with phases in the evolution of civilization, from which more sophisticated conceptual understanding could be derived. Unifying the psychological and historical dimensions of experience through such principles was a major theoretical advance. Practically, they would be manifested and directed through the instructional vehicle of occupations.

\section{Occupations}

Kliebard (1995) describes Dewey's notion of occupations as "the characteristic activities in which the individual or society engaged and the ability of those individuals to achieve command of their environment" (p. 61). Activities such as gardening, printing, and building were not just jobs people did; they were the unity of societal progress and individual expression, encoded in material practices. "Industrial arts," Dewey (1958) wrote, "are the type-forms of experience that bring to light the sequential connections of things with one another" (p. 84). This was another basic assumption, which Dewey elaborated as a curricular principle. Occupations, in his logic, "shall not be mere practical devices or modes of routine employment, the gaining of better skills as cooks, seamstresses, or carpenters, but active centers of scientific insight into natural materials and processes, points of departure whence children shall be led out into a realization of the historic development of man" (1899, p. 462). The instructional goal was therefore to progressively organize tasks so the seeming coherence of simple operations could be unraveled and interpreted, revealing a rich history as well as a responsiveness to innovation. Day-to-day schooling would therefore involve active participation by children in tasks that constituted "making a living" throughout history, forms of social practice developed to bring nature under human control-the fundamental process of living socially in the world.

A surface feature of occupations was that children would learn by cooperatively solving problems, a notion that, as we pointed out earlier, has become axiom- 
atic in the EBL literature (e.g., Savery \& Duffy, 1996). But, like interest and relevance, grasping Dewey's deeper conception of problem solving requires attention to his overall framework, especially the role of subject matter. Speaking to this point, Kliebard (2006) wrote, "when human beings eat, they do not eat in general, they eat food. They do not simply play an instrument, they play something on that instrument" (p. 115). Problem solving, in Dewey's framework, was indivisible from subject matter; he did not mean it in general. In occupations, children participated firsthand in situations that had been intentionally orchestrated to recapitulate problems that had vexed humanity at various phases in the development of civilization, with the conceptual and material tools that were available at the time (see e.g., Tanner, 1997).

Hands-on activity played a crucial role in learning through occupations, for essential to their pedagogical effectiveness was the way tools functioned, that is, the requisite equipment and its customs for use. Stemming from his early study of Hegel, Dewey shared with Marx the view that labor was the paradigmatic expression of human creativity, the nexus of cultural knowledge communicated through material artifacts, and the starting point for individual and collective innovation (Garrison, 1995; Miettinen, 2001, 2006). This meant that tools played a key role in mastering mature concepts. Existing societal conventions-what he called prejudices-were not only held cognitively, but were "welded into the genuine materials of first-hand experience" and "may become organs of enrichment if they are detected and reflected upon" (Dewey, 1958, p. 37). Occupations were therefore not simply enriching pedagogical devices or pretexts for cooperative learning; they were instrumental in mastering subject matter knowledge organized "longitudinally" according to culture epochs. Using them in this way "permits and requires greater definiteness, corresponding to the gain of mental concentration made in the yeargreater abstractness, if the word is used in the sense of an intentional simplification of existing experience, through elimination of certain elements and emphasis of others, conducted to bring out a special idea" (Dewey, 1900, p. 222). Importantly, gleaning "special ideas" through solving historical problems was central both to progressively achieving more complex forms of thinking-what Vygotskyans might call the appropriation of scientific concepts (Mayer, 2009) - and to gaining control over modern social and technological processes. Such special ideas, once worked out and reflected upon during lessons, could be directed to current problems as a "method of analysis of existing social life, not as affording information about something past and gone" (1900, p. 223). Problem solving therefore involved the shared use of culturally available tools in progressively engaging with humankind's historical challenges, and was to be the central method in Dewey's curriculum, the realization of experience at any given instance and the fodder for subsequent reflection and experimentation. Rather than being an end in itself, problem solving was a means of grasping scientific principles so children could direct them to modern social and technological issues.

Despite moving away from the specifics of the culture epochs curriculum after leaving Chicago (Fallace, 2010), what Dewey continued to cultivate through 
his curricular conception of experience-subject matter knowledge organized systematically to help children jointly understand and direct technological and economic processes as well as their own development-was an aesthetic and "unalienated" (Westbrook, 1993) engagement with labor and a close appreciation for the role of modern science in expanding human capabilities. Such self-conscious engagement in practical conduct and intellectual inquiry signaled what Dewey called "the method of experimental intelligence." This was a social imperative as much as it was an individual, reflective trait:

The method of experimental intelligence as the method of action cannot be established as a constant and operative habit of mind and character apart from education. But it cannot be established within education except as the activities of the latter are founded on a clear idea of the active social forces of the day, of what they are doing, of their effect, for good and harm, upon values, and except as this idea and ideal are acted upon to direct experimentation in the currents of social life that run outside the school and that condition the educational meaning of whatever the school does.

(Dewey, 1933, pp. 103)

When, in Experience and Education (1938), Dewey critiqued other curricular ideologies-humanism, vocationalism, "child centered" progressivism-for not having a defensible philosophy of experience, it was not because they were not political enough, not active or cooperative enough, did not take the learner's interests seriously, or did not adequately emphasize subject matter, for they variously included these elements. It was on the grounds that they failed as curriculum theories capable of fostering the expansion of cultural resources and development of individuals as well as for providing the means for experimenting with solutions to societal problems accelerating under rampant capitalism. This is the conceptual apparatus Dewey sought to provide when he applied experience to education.

\section{Discussion and Implications}

In foregrounding Dewey's cultural and economic analysis and his specific curricular logic as we have here, the profoundly social nature of experience comes into sharper view. Our argument suggests that Dewey was not primarily concerned with meaningful individual learning, with designing interventions to foster "a limited field of mutually kindly relations among individuals" (1989, p.125), or even with inciting civic participation as such. "The problems to be solved are general, not local," he wrote. "They concern complex forces that are at work throughout the whole country, not those limited to an immediate and almost face-to-face environment" (Dewey, 1999b, p. 46). With this sentiment in mind, he developed experience simultaneously as a basis for systematically engaging students in learning activities that would support historically new forms of social and individual growth, and for reconciling theoretical problems across seemingly incommensurable domains, from individual motivation to the historical path of civilization. At root, experience was 
central to an educational and conceptual system Dewey developed to address some of the most troubling historical, social, economic, and political problems affecting schooling in the early twentieth century.

It is clear the complex philosophical and practical work experience was made to do when Dewey applied it to educational problems. The term's burden was compounded by its perpetual confusion with commonsense psychological meanings, a main reason he abandoned it (Dewey, 1981). The continued tendency to confuse the term in this way, or to break it down into fragments-such as active learning, problem solving, and reflection-quickly puts such key ideas out of touch with his broader theoretical framework and his radical political agenda. One implication is that strong links between Dewey's conception of experience and modern EBL practices such as internships, wilderness programs, and simulation exercises have yet to be firmly established. In addition, not only does a piecemeal interpretation undermine strong claims to Deweyan parentage, it seems unlikely to help clarify his overall philosophy or apply it in fresh ways to contemporary problems.

Finding value in elements of Dewey's theory may, however, be inevitable given how impracticable Dewey's full program now seems, and how limited his impact on education actually was (Kliebard, 1995; Westbrook, 1993). We doubt this is simply a failure of imagination; the intermittent success of experience-based reforms throughout the twentieth century suggests that schools are resilient places that shape reforms, rather than reforms shaping schools (Tyack \& Cuban, 1995). And, even where modern reforms have achieved widespread success-service learning provides one example (Giles \& Eyler, 1994) — many instances actually look very similar to initiatives that Dewey only equivocally supported, such as manual training, the project method, and the experience curriculum (Kliebard, 1995). Nonetheless, engaging more carefully with Dewey's full curriculum theory may help envision new possibilities given current conditions and priorities.

We also wish to raise the possibility that Dewey's notion of experience, as we have presented it, may actually bear more of a resemblance to contemporary programs that do not claim to be experience based per se, than to those that have made this claim explicitly. We briefly entertain this by turning now to current work that elaborates on the priorities we have outlined, namely the critical pragmatism of Kadlec (2007), Glaude (2007), and Green (2008), and the radical-local teaching approach described by Hedegaard and Chaiklin (2005).

\section{Critical pragmatism}

Surprisingly, the social justice and critical pedagogy literature often cites Dewey's work without drawing on his critiques of political economy sketched above. However, we see clear parallels: in general, critical pedagogy analyzes the multiple ways economic and social practices infuse schooling (and educational thought) to perpetuate social inequalities (Apple, 1990; Delpit, 1995; Fletcher, 2000; Freire, 1988; Giroux, 2001). Unlike the account of Dewey's thought we offer here, critical pedagogy has been repeatedly criticized for its focus on analysis without providing adequate resources 
for responding to the oppressive circumstances it critiques (Ellsworth, 1989). When it does offer curricular direction, the focus is often on fostering agency by engaging in successful political action. ${ }^{2}$

In contrast, Dewey combined social and economic critique with a conception of individual agency that strove to concretely realize democratic social relations through the workings of culture. The critical potential of Dewey's far-reaching, pragmatic thought is the focus of a growing body of contemporary work in critical pragmatism (e.g., Glaude, 2007; Green, 1999, 2008; Harris, 1999) with roots also in W. E. B. Dubois's and Alain Locke's work. While a full survey is beyond the scope of this discussion, this literature offers resources for elaborating the educational implications of Dewey's work and his theory of experience in particular. Kadlec (1996) made this point when she argued that Dewey's conception of experience can underwrite a democratic social reconstruction where "lived experience is a tool for meaningful democratic struggle to the extent that it consists of a critical and forward-thinking perception of the private and shared consequences of our actions" (p. 522).

One of the most profound aspects of Dewey's framework of experience is its attempt to develop a unified theory of individual agency with the awareness that capitalism influences us "all the way down." The result is that Dewey provides a vision for individual agency grounded within the conditions of social oppression. The difference turns on the pragmatic dimensions of experience as central to knowing. As Kadlec (1996) argued,

For critical pragmatists such as Dewey, the point of reflective inquiry is not to generate final principles, but rather to improve our capacity for tapping into the critical potential of lived experience in a world defined by flux and change. The political, social, and economic challenges we face require that we arm ourselves not with fixed absolutes, but rather with a commitment to open-ended and flexible inquiry aimed not at final consensus about our aims, but rather at achieving a greater understanding of the consequences of our practices and policies. (p. 542)

Contemporary critical pragmatists share Dewey's commitment to a social theory of individualism, which challenges the liberal conception still dominating educational thought - that individualism is marked by independence from others. Instead, critical pragmatists maintain that individualism emerges through acting with others. They are putting this ontological assumption to work to reconstruct local democratic relationships as well as the features of industrial capitalism that shape them. Critical pragmatists might benefit from studying the specific curricular models Dewey designed to foster collaboration, creativity, and disciplinary knowledge so children can self-consciously engage in the reconstruction of social practices while developing the habits of critical inquiry necessary for realizing themselves as democratic agents. 


\section{Radical-local teaching and learning}

Where critical pragmatists extend the Deweyan themes of individual agency and social reconstruction, Hedegaard and Chaiklin (2005), working in the Marxist dialectical tradition of cultural-historical activity theory, indirectly develop other themes. They cite Dewey only once in their text, yet their program can be read as an extension of Deweyan priorities; specifically, their "radical-local" approach to teaching and learning is aimed at helping children connect everyday knowledge with general or scientific knowledge, use historically derived models as a tool for solving contemporary problems, personally identify with the motives of various social practices, and advocate for improved social conditions. They wrote:

The idea of radical-local teaching and learning is to plan and implement teaching practices that serve to develop a pupil's knowledge of subject-mater content in a way that is related to the cultural-historical conditions of the children's lives. This knowledge should serve as intellectual tools that can be used to understand and act in relation to those conditions-both the specific historically developed conditions in the children's neighborhood, and larger patterns that reflect historical epochs or general cultural change within traditions of practice. (p. 101)

Several features of Hedegaard and Chaiklin's (2005) radical-local approach are comparable to Dewey's curricular logic, viewable through their example of an afterschool program involving Puerto Rican middle schoolers in New York City. First is the development of teaching practices based on a preemptory historical analysis of local conditions pertaining to the children's particular cultural legacy (in their example, how and why Puerto Ricans followed particular settlement patterns). This feature resembles the kind of analysis a teacher would have needed to do to understand the present-day ramifications of a culture epoch. Second is the articulation of "core models" comprised of basic conceptual elements of social and

Figure 1. Core Model of Basic Conceptual Relations Used to Plan NYC Curriculum Unit $^{3}$

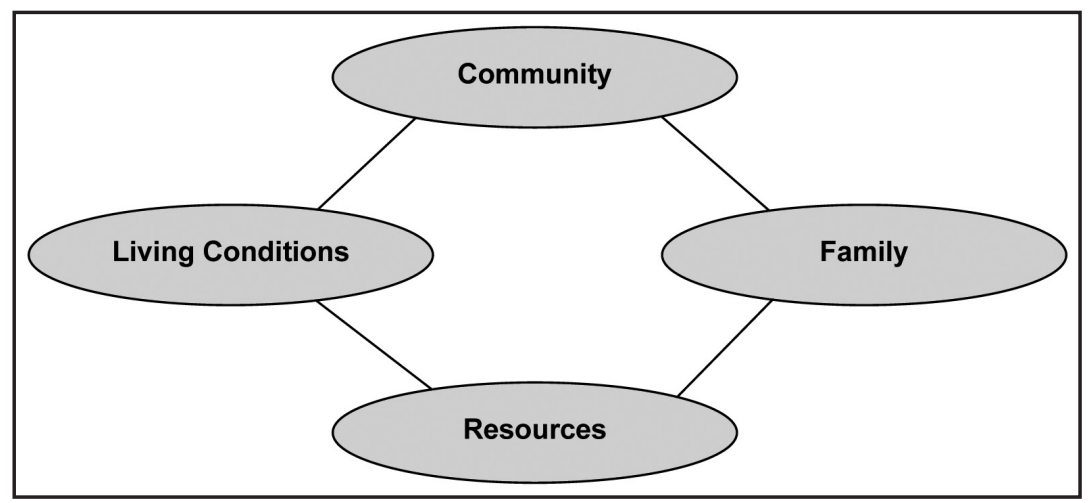


economic relations among people, used for planning children's activities. This feature resembles the distillation of special ideas students would be expected to glean in Dewey's program (Figure 1 illustrates these elements in Hedegaard and Chaiklin's example). Lastly, children's appropriation of these basic conceptual relations was multiphasic, moving through the development of personal goals and conceptual models via hands-on exercises and field research, to later using their models to analyze historical and modern social conditions and make specific recommendations for improving conditions within their communities. The intent behind these methods was to help children acquire "concepts, methods and motives that enable new possibilities for action, investigation and reflection about aspects of one's life" (p. 184). We see these methods and priorities as analogous to Dewey's use of occupations as an engaging means of imparting conceptual tools for analyzing present-day conditions.

Two additional features of the radical-local approach deserve mention. First, its developmental aims were not conceived abstractly in the unit Hedegaard and Chaiklin describe, but in relation to the concrete historical and social conditions that form the basis for children's everyday knowledge. This strikes us as highly consistent with Dewey's pragmatism and his rejection of dualist epistemologies. Second, teachers did not teach the core model to children directly, but rather planned tasks involving collaboration with each other and with community members in processes of inquiry; in other words, they discovered these conceptual relations through their own labor during specially conceived learning experiences, meant in the expansive sense we have attributed to Dewey. These links may give reason to think of activity in the CHAT sense as roughly equivalent to experience in Dewey's sense (cf. Mayer, 2009; Miettinen, 2001).

Our discussion of current trends in critical pragmatism, which is extending Dewey's work on agency and social transformation, and cultural-historical activity theory, which is extending the themes of historical analysis, concept development, and material activity as crucial to learning and development, were only cursory. Interestingly, neither identify strongly with Dewey's concept of experience, even though we see clear parallels that could be elaborated in the future. One benefit of incorporating experience into these lines of scholarship is the breadth of Dewey's writing on the topic, which could help scholars integrate other philosophical domains, such as aesthetics and ethics, into their programs.

\section{Conclusion}

In comments about his decision to replace experience with culture upon revising Experience and Nature, Dewey remarked that he had used experience "to designate, in a summary fashion, all that is distinctively human" (1981, p. 331). He lamented that experience had become almost exclusively identified with "experience in the sense of the psychological, and the psychological has become established as that which is intrinsically psychical, mental, private" (p. 362). This was never his intent. In 
contrast, he approvingly cited the anthropologist Bronislaw Malinowski, who wrote: "culture is at the same time psychological and collective" (p. 364). Articulating the philosophical relationships between the psychological, social, and natural worlds, while establishing a democratic vision for rationally deliberated, just ends, remained Dewey's lifelong project. Experience served this project for a time and it may yet provide new ideas for addressing present-day educational and social problems.

\section{Notes}

1. For example, classical critical theorists like Max Horkheimer outright reject Dewey's pragmatism as contributing to critical theory (see Horkheimer, 1947). More recently, see Frank Margonis's (2009) rejection of Dewey's educational program due to what he reads as Dewey's implicit racism.

2. For example, Allman argues: "critical perception of reality enables people to know what needs changing" (1999; Hill, 2008; see also McLaren, 2003). The task, these theorists argue, is to act for such change, thereby seeing agency as evidence that students are countering class oppression.

3. Hedegaard \& Chaiklin, 2005, p. 114. Copyright Marianne Hedegaard and Seth Chaiklin and Aarhus University Press. Used with permission.

\section{References}

Allman, P. (1999). Revolutionary social transformation: Democratic hopes, political possibilities and critical education. Westport, CT: Bergin \& Garvey.

Andresen, L., Boud, D., \& Cohen, R. (1999). Experience-based learning. In G. Foley (Ed.), Understanding adult education and training (pp. 225-239). Sydney, Australia: Allen \& Unwin.

Apple, M. (1990). Ideology and Curriculum. New York: Routledge.

Apple, M., Au, W., \& Gandin, L. A. (Eds.). (2009). The Routledge international handbook of critical education. New York: Routledge.

Beard, C., \& Wilson, J. P. (2006). Experiential learning: A best practice handbook for educators and trainers. London: Kogan Page.

Boud, D., Keogh, R., \& Walker, D. (Eds.). (1985). Reflection: Turning experience into learning. New York: Kogan Page.

Carver, R. L., \& Enfield, R. P. (2006). John Dewey's philosophy of education is alive and well. Journal of Education and Culture, 22(1), 55-67.

DeFalco, A. (2010). An analysis of John Dewey's notion of occupations: Still pedagogically viable? Journal of Education and Culture, 26(1), Article 7. Retrieved June 15, 2010, from http://docs.lib.purdue.edu/eandc/vol26/iss1/art7 Delpit, L. (1995). Other People's Children. New York: The New Press.

Dewey, J. (1896a). Interpretation of culture-epoch theory. In J. A. Boydston (Ed.), John Dewey, the early works (Vol. 5, pp. 247-253). Carbondale, IL: Southern Illinois University Press.

. (1896b). The university school. In J. A. Boydston (Ed.), John Dewey, the early works (Vol. 5, pp. 436-441). Carbondale, IL: Southen Illinois University Press. 
. (1897). My pedagogic creed. The School Journal, 54(3), 77-80.

. (1899). The school and social progress. In J. J. McDermott (Ed.), The philosophy of John Dewey (pp. 454-467). Chicago, IL: University of Chicago Press.

. (1900). Group IV. Historical development of inventions and occupations. In J. A. Boydston (Ed.), John Dewey: The middle works (Vol. 1, pp. 222-224). Carbondale, IL: Southen Illinois University Press.

. (1916). Democracy and education. New York: Free Press.

. (1932). American education past and future. In J. A. Boydston (Ed.), John Dewey, the later works (Vol. 6, pp. 90-98). Carbondale, IL: Southern Illinois University Press.

. (1933). Underlying philosophy of education. In J. A. Boydston (Ed.), John Dewey, the later works (Vol. 8, pp. 77-103). Carbondale, IL: Southern Illinois University Press.

. (1934a). Dewey outlines utopian schools. In J. A. Boydston (Ed.), John Dewey, the later works (Vol. 9, pp. 136-140). Carbondale, IL: Southern Illinois University Press.

. (1934b). Why I am not a communist. In J. A. Boydston (Ed.), John Dewey, the later works (Vol. 9, pp. 91-95). Carbondale, IL: Southern Illinois University Press.

. (1938). Experience and education. New York: Macmillan.

. (1958). Experience and nature. New York: Dover. (Original work published 1925).

. (1980). Art as experience. New York: Perigee Books. (Original work published 1934).

. (1981). Experience and nature: A re-introduction. In J. Ratner (Ed.), John Dewey, the later works (Vol. 1, pp. 330-361). Carbondale, IL: Southern Illinois University Press. (Original work published n.d.).

. (1989). Freedom and culture. Amherst, NY: Prometheus Books. (Original work published 1939).

. (1990). The school and society/The child and the curriculum. Chicago: University of Chicago Press. (Original work published 1956).

. (1991). Liberalism and social action. Amherst, NY: Prometheus Books. (Original work published 1935).

. (1999a). Capitalistic or public socialism? In J. Dewey (Ed.), Individualism old and new (pp. 50-58). Amherst, NY: Prometheus Books. (Original work published 1930).

. (1999b). Individualism old and new. Carbondale, IL: Prometheus Books. (Original work published 1929).

Dewey, J., \& Tufts, J. H. (1909). Ethics. New York: Henry Holt.

Ellsworth, E. (1989). Why doesn't this feel empowering? Working through the repressive myths of critical pedagogy. Harvard Educational Review, 59(3), 297-324. 
Fallace, T. D. (2008). John Dewey and the savage mind: Uniting anthropoligical, psychological, and pedagogical thought, 1894-1902. Journal of the History of the Behavioral Sciences, 44(4), 355-349.

_. (2010). Was Dewey ethnocentric? Reevaluating the philosopher's early views on culture and race. Educational Researcher, 39(6), 471-477.

Fletcher, S. (2000). Education and emancipation: Theory and practice in a new constellation. New York: Teacher's College Press.

Freire, P. (1988). Pedagogy of the Oppressed. New York: Continuum.

Garrison, J. (1995). Dewey's philosophy and the experience of working: Labor, tools, and language. Synthese, 105(1), 87-114.

Giles, D. E. J., \& Eyler, J. (1994). The theoretical roots of service learning in John Dewey: Toward a theory of service learning. Michigan Journal of Community Service Learning, 1(1), 77-85.

Giroux, H. (2001). Theory and resistance in education. Westport, CT: Bergin and Garvey.

Glaude, E. S. (2007). In a shade of blue: Pragmatism and the politics of Black America. Chicago: University of Chicago Press.

Green, J. M. (1999). Deep democracy: Community, diversity, and transformation. Lanham, MD: Rowman \& Littlefield. . (2008). Pragmatism and social hope. New York: Columbia University Press.

Harris, L. (1999). The critical pragmatism of Alain Locke: A reader on value theory, aesthetics, community, culture, race, and education. Lanham, MD: Rowman \& Littlefield.

Hill, D. (2008). Resisting neo-liberal global capitalism and its depredations: Education for a new democracy. In D. E. Lund \& P. R. Carr (Eds.), Doing democracy: Striving for political literacy and social justice (pp. 33-49). New York: Peter Lang.

Horkheimer, M. (1947). The eclipse of reason. New York: Continuum Press.

Kadlec, A. (2007). Dewey's critical pragmatism. Lanham, MD: Lexington Books.

Kellner, D., \& Share, J. (2007). Critical media literacy is not an option. Learning Inquiry, 1, 59-69.

Kliebard, H. M. (1995). The struggle for the American curriculum, 1893-1958 (2nd ed.). New York: Routledge.

. (2006). Dewey's reconstruction of the curriculum. In D. T. Hansen (Ed.), John Dewey and our educational prospect: A critical engagement with Dewey's Democracy and Education (pp. 113-127). Albany, NY: SUNY Press.

Kolb, D. (1984). Experiential learning: Experience as the source of learning and development. Englewood Cliffs, NJ: Prentice-Hall.

Margonis, F. (2009). John Dewey's racialized visions of the student and classroom community. Educational Theory, 59(1), 17-39.

Maxwell, J. A. (2005). Qualitative research design: An interactive approach. Thousand Oaks, CA: Sage Publications. 
Mayer, S. J. (2009). Dewey's dynamic integration of Vygotsky and Piaget. Journal of Education and Culture, 24(2), 6-24.

McLaren, P. (2003). Critical Pedagogy: A look at the major concepts. In A. Darder, M. Baltodano \& R. Torres (Eds.), The critical pedagogy reader, 61-83. New York, NY: RoutledgeFalmer.

Miettinen, R. (2001). Artifact mediation in Dewey and in cultural-historical activity theory. Mind, Culture, and Activity, 8(4), 297-308.

. (2006). Epistemology of transformative material activity: John Dewey's pragmatism and cultural-historical activity theory. Journal for the Theory of Social Behavior, 36(4), 389-407.

Moon, J. (2004). A handbook of reflective and experiential learning. London: RoutledgeFalmer.

Savery, J. R., \& Duffy, T. M. (1996). Problem based learning: An instructional model and its constructivist framework. In B. G. Wilson (Ed.), Constructivist learning environments: Case studies in instructional design (pp. 135-150). Englewood Cliffs, NJ: Educational Technology Publications.

Starnes, B. A. (1999). The Foxfire approach to teaching and learning: John Dewey, experiential learning, and the core practices. Charleston, WV: ERIC Clearinghouse on Rural Education and Small Schools.

Tanner, L. (1997). Dewey's laboratory school: Lessons for today. New York: Teachers College Press.

Tyack, D. B., \& Cuban, L. (1995). Tinkering toward utopia: A century of public school reform. Cambridge, MA: Harvard University Press.

Westbrook, R. B. (1993). John Dewey. Prospects: The quarterly review of comparative education, 23(1/2), 277-291.

Wurdinger, S. (2005). Using experiential learning in the classroom. Lanham, MD: Scarecrow Education.

Jayson Seaman is Assistant Professor of Kinesiology and Affiliate Assistant Professor of Education at University of New Hampshire.

E-mail: jayson.seaman@unh.edu

Peter J. Nelsen is Assistant Professor of Educational Foundations at Appalachian State University. 